\title{
Parameters of European Exhibition Centres
}

\section{Charakteristiky evropských veletržních areálů}

\section{Lenka Štěpánková}

Tutor: doc. Ing. arch. Maxmilian Wittmann, Ph.D., Ústav urbanismu, Fakulta architektury, Vysoké učení technické v Brně

E-mail address: xastepankoval@stud.fa.vutbr.cz

\begin{abstract}
Large exhibition centres in European cities represent a specific type of urban space with their own unique parameters. Whilst formal parameters deal with scale and form, functional parameters pertain mainly to logistics and the operating of the venue. In this paper, other important parameters are included with those already referenced. Financial parameters such as the total exhibition area available, total build up area and total venue area are combined. The results speak about a venues capacity or their spatial potential and can be used to predict the need for further transformation or relocation of the certain venue in the future.
\end{abstract}

KEYWORDS: exhibition centres; form; function; financial parameters; transformation

\begin{abstract}
ABSTRAKT: Veletržní a výstavní areály jsou zkoumány jako zcela svébytný typ městského prostoru ze tř́ různých perspektiv. Formální charakteristiky popisují jeho měřítko a skladbu hmot, funkční charakteristiky zachycují způsob využívání, provozní vztahy v rámci areálu a jeho vazby na okolí. Finanční charakteristiky vycházejí ze vztahu prostorových parametrů, jako je celková plocha, zastavěná plocha, výstavní plocha a plocha akcí. Výsledný komplexní popis představuje teoretický základ pro výzkum transformačních procesů, které jsou pro veletržní a výstavní areály typické.
\end{abstract}

KLÍČOVÁ SLOVA: výstavní areály; veletržní areály; forma; funkce; finance; transformace 


\section{Úvod}

Určení hlavních charakteristik veletržních areálů slouží k pochopení podstaty transformačních procesů, typicky např́iklad důvodů vedoucích k rozšíření nebo relokaci areálu, a k popisu vztahu areálů $\mathrm{k}$ městu. Tento př́spěvek si klade za cíl stručně shrnout standardní charakteristiky areálů, které představují forma a funkce, a rozšířit je o finanční charakteristiky areálů.

\section{Vymezení předmětu zájmu, definice pojmů}

K vymezení veletržních areálů slouží definice UFI, podle které se areálem (v anglickém originálu textu je použit výraz venue neboli místo) rozumí „jakýkoliv soubor veřejných budov s celkovou vnitřní výstavní plochou minimálně $5000 \mathrm{~m}^{2}$, kde jsou pravidelně pořádány různé typy akcí, jako jsou výstavy, veletrhy nebo predváděcí akce pro veřejnost. Může jít o budovy primárně určené $k$ výstavním účelưm nebo mohou být výstavní prostory součástí komplexu budov sloužícího i jiným účelum (hotely, arény, sportovní areály nebo zábavní parky).“(překlad autorka). Přehled UFI rozlišuje areály velké (nad $100000 \mathrm{~m}^{2}$ výstavní plochy), střední (20 000-100 $000 \mathrm{~m}^{2}$ výstavní plochy) a malé (do $20000 \mathrm{~m}^{2}$ výstavní plochy). Velkých areálů s rozlohou nad $100000 \mathrm{~m}^{2}$ existuje podle přehledu UFI v Evropě celkem 38.

Definice výstavních areálů vychází ze standardů BIE pro světové výstavy EXPO. Podle těchto kritérií musí mít výstavní akce dané konkrétní téma, vymezené místo a omezenou dobu trvání. Je předem známý organizátor akce (hostitelský stát, instituce nebo firma), účastníky jsou státy nebo organizace (firmy). V souladu se standardy BIE a pod záštitou této organizace proběhly v Evropě od konce 2. světové války 4 velké světové výstavy s rozlohou areálu 110-215 ha, dále 15 velkých mezinárodních zahradních výstav, u kterých se velikost areálu pohybovala v rozmezí 50-100 ha, a 18 specializovaných velkých mezinárodních výstav, u kterých byl rozptyl v udané velikosti areálu 6-100 ha. Tyto charakteristiky platí přiměřeně také pro menší akce lokálního významu.

Společné charakteristiky i odlišnosti výstavních a veletržních areálů ukazuje tab. 1 .

\section{Formální charakteristiky}

Jako hlavní předmět zkoumání byly zvoleny největší veletržní areály v Evropě, které jsou porovnávány s areály pro výstavní akce na globální nebo přinejmenším celostátní úrovni. Ze srovnávání byly vyloučeny menší veletržní komplexy (venue), které se v městském prostředí nechovají jako areály, nýbrž prostě jako budovy nebo soubor 
budov. Mezi hlavní formální charakteristiky, které odlišují výstavní a veletržní areály, patř́i měřítko budov a struktura zástavby, jak je vidět na př́íladu Bruselu a Hannoveru na obr. 1 a obr. 2 .

\begin{tabular}{|c|c|c|}
\hline & Veletržní areály & Výstavní areály \\
\hline $\begin{array}{l}\text { Společné } \\
\text { charakteristiky } \\
\text { (= definice areálu) }\end{array}$ & \multicolumn{2}{|c|}{$\begin{array}{l}\text { Uzavřený prostor o značné rozloze ( } 50-200 \text { ha) s více budovami a volnými } \\
\text { plochami mezi nimi, skontrolovaným vstupem osob, integrovaný do } \\
\text { městského prostř̌edí především dopravními systémy, které umožňují } \\
\text { bezproblémový př́jezd velkého počtu návštěvníků na místo konání akce } \\
\text { vareálu. Pro oba typy areálů je charakteristické zvýraznění vstupů. }\end{array}$} \\
\hline $\begin{array}{l}\text { Funkční } \\
\text { charakteristiky }\end{array}$ & $\begin{array}{l}\text { Soubor budov pro opakované } \\
\text { konání akcí, důraz na flexibilitu a } \\
\text { logistiku výstavních prostor } \\
\text { s možností rychlé obměny } \\
\text { prostorového uspořádání pro rủzné } \\
\text { typy akcí. Budovy vareálu se } \\
\text { přestavujív dlouhodobém časovém } \\
\text { horizontu. }\end{array}$ & $\begin{array}{l}\text { Místo upravené pro jednorázovou } \\
\text { akci; dlouhé období prípravy } \\
\text { zahrnuje také trvalé i dočasné úpravy } \\
\text { města mimo samotný výstavní areál. } \\
\text { Po skončení akce následuje předem } \\
\text { plánovaná proměna celého areálu } \\
\text { včetně demontáže budov nebo } \\
\text { změny jejich využití. }\end{array}$ \\
\hline $\begin{array}{l}\text { Formální } \\
\text { charakteristiky }\end{array}$ & $\begin{array}{l}\text { Velké měřítko budov, jednoduché } \\
\text { hmotové členění, typický je halový } \\
\text { charakter zástavby a spojování } \\
\text { objektů. Architektonicky jsou } \\
\text { zpravidla zvýrazněné významnější } \\
\text { budovy nebo vstupní místa. }\end{array}$ & $\begin{array}{l}\text { Menší měřítko budov, objekty } \\
\text { nejčastěji řešené jako solitérní, } \\
\text { množství atypických staveb. Častá } \\
\text { jsou mimořádná architektonické } \\
\text { řešení. Krajinné a parkové úpravy, } \\
\text { důraz na řešení veřejných } \\
\text { prostranství, kvalitu povrchů a } \\
\text { mobiliáře. }\end{array}$ \\
\hline $\begin{array}{l}\text { Finanční } \\
\text { charakteristiky }\end{array}$ & $\begin{array}{l}\text { Hospodářské výsledky hodnocené } \\
\text { na bázi opakujících se cyklů (roční, } \\
\text { dvouleté apod.), předpokládá se } \\
\text { návratnost vstupní investice } \\
\text { z výnosů } \quad \text { z dlouhodobého } \\
\text { pravidelného provozu areálu. Důraz } \\
\text { na efektivitu provozu. }\end{array}$ & $\begin{array}{l}\text { Jediný ekonomický cyklus o třech } \\
\text { fázích: príiprava areálu, průběh akce, } \\
\text { následná úprava nebo zrušení areálu. } \\
\text { Ne vždy je zaručena návratnost } \\
\text { investice, respektive nenívždy možné } \\
\text { prínos akce prímo porovnávat } \\
\text { s vynaloženými náklady. }\end{array}$ \\
\hline
\end{tabular}

Tab. 1. Přes vzájemné odlišnosti výstavních a veletržních areálů existuje určitá míra kompatibility. Výstavní areály mohou být po skončení akce transformovány ve veletržní areály (Řím 1953, Plovdiv 1981, Brno 1928, Poznaň 1929, Stuttgart-Killesberg 1950) nebo může být naopak veletržní areál využit k uspořádání výstavy (Lyon 1949, Budapešt 1971, Hannover 2000). Výstavní areál v Bruselu, který původně vznikl pro Expo 1937, slouží jako stálý veletržní areál, přičemž v roce 1958 byl znovu využit a dočasně rozšířen pro účely světové výstavy Expo 1958.

\section{Funkční charakteristiky}

Stálé veletržní areály jsou z funkčního hlediska velmi výrazně utvářeny podle poža- 
davků provozu a logistiky. Je zde patrný rozdíl mezi areály navrženými na okraji města, jejichž prostorová koncepce tyto požadavky beze zbytku reflektuje (obr. 3), a mezi areály historickými, které byly původně navrženy jako výstavní a postupně vrostly do městské struktury (obr. 4 a obr. 5).
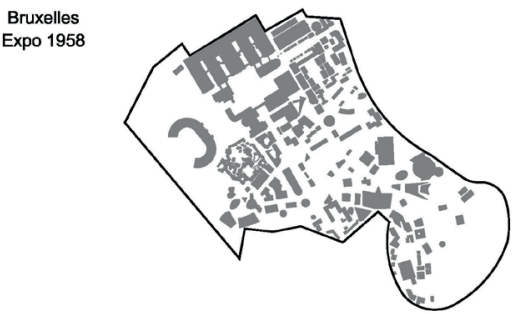

Brussels Expo
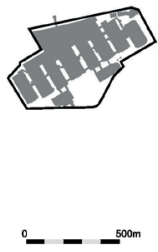

Obr. 1. Srovnání výstavního areálu při Expo 1958 a stálého veletržního areálu Brussels Expo. Kromě rozdílné velikosti areálu při Expo 1958 a stávajícího veletržního a kongresového areálu Brussels Expo je dobře viditelný právě rozdíl ve struktuře a měřítku zástavby.

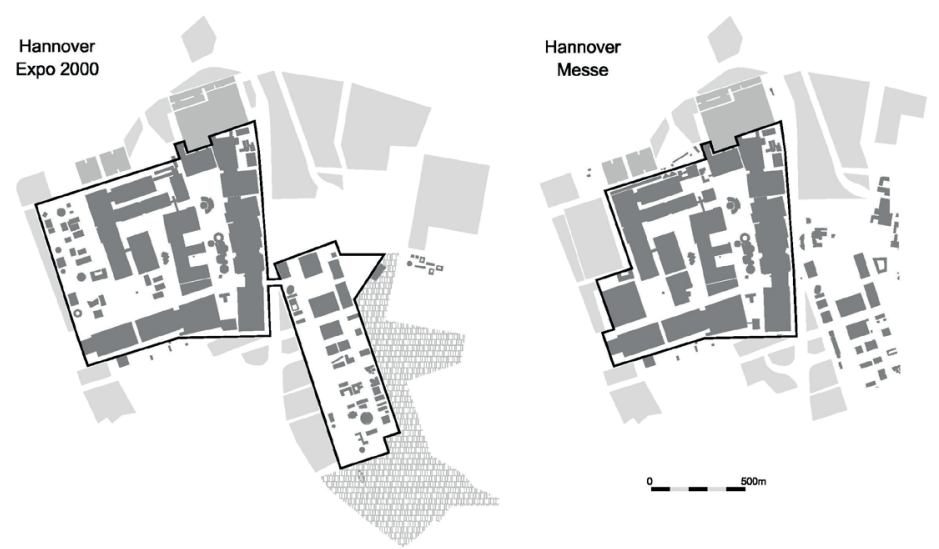

Obr. 2. Schéma zachycuje stav areálu při Expo 2000 a současnou podobu výstaviště v Hannoveru. Přestože se v době konání Expo 2000 jednalo o největší veletržní areál na světě, byl pro výstavu Expo 2000 ještě rozšířen o plochy s dočasnými národními pavilony a parkově upravené odpočinkové plochy. Př́íprava na výstavu Expo 2000 byla spojená mj. s investicemi do dopravní infrastruktury, která i po akci dál slouží veletržnímu areálu. 


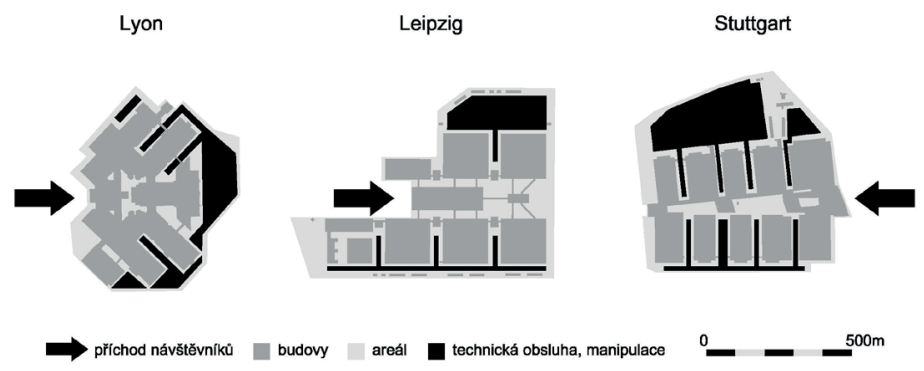

Obr. 3. Ukázka rozmístění tras technické obsluhy a manipulačních prostor u areálů, které byly vybudovány v různých obdobích na okraji města. Výstaviště Eurexpo v Lyonu (po Paříži největší výstavní areál ve Francii) bylo otevřeno v roce 1984, výstaviště v Lipsku v roce 1996 a výstaviště ve Stuttgartu v roce 2007. Pro srovnání je zachováno jednotné měŕítko areálů.

\section{Barcelona Montjuic Barcelona Montjuic}

\section{Automobile 2019}
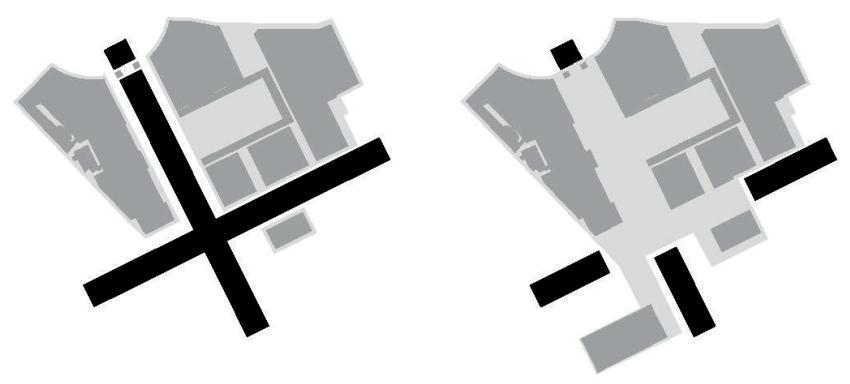

\section{budovy areál veřejné komunikace}

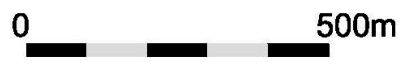

Obr. 4. Výstaviště Barcelona Montjuic, které vzniklo v roce 1929 v kontaktu s běžnou městskou zástavbou, je rozdělené širokým městským bulvárem a menší akce se konají odděleně v jednotlivých halách po obou stranách. Pro srovnání je naznačen prostor velké akce za úplného uzavření veřejné komunikace při Automobile Barcelona 2019. 


\section{Basel}

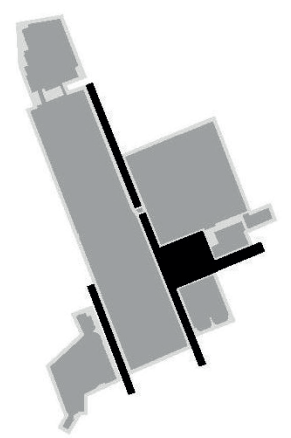

\section{budovy areál $\square$ veřejné komunikace}

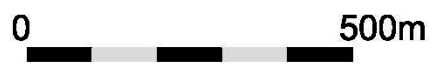

Obr. 5. Schematické vyznačení prostorového vztahu mezi veřejným prostorem a veletržním areálem v Basileji. Mezi třicítkou největších veletržních areálů v Evropě je areál v Basileji jediný s celkovou rozlohou pod $100000 \mathrm{~m}^{2}$ a při zběžném pohledu se jeví jako soubor budov. Nicméně jednotlivé pavilony mají sofistikovaný systém kontroly vstupů a servisních vjezdů a jsou v úrovni nad ulicemi propojeny lávkami, takže i tento areál je ve skutečnosti provozně z města zcela vyčleněný.

\section{Finanční charakteristiky}

Při zkoumání finančních charakteristik byl důraz kladen na ty parametry areálů, které jednotlivě, ale především ve vzájemném poměru vypovídají o prostorovém potenciálu v ekonomickém smyslu.

Výstavní plocha je část vnitřní plochy výstavních hal určená čistě k výstavbě veletržních expozic (bez prostoru komunikací, bezpečnostních a manipulačních ploch a technického zázemí).

Zastavěná plocha je část areálu zastavěná budovami. Jsou do ní zahrnuty veškeré budovy, tedy kromě výstavních hal také kongresové haly, kancelářské budovy veletržní správy, technické budovy, sklady vybavení. 
Celková plocha areálu je vymezena nad mapovými podklady. V zásadě jde o nejtěsnější možnou obvodovou křivku zahrnující všechny výstavní haly a nezbytně nutné související manipulační plochy. Samostatné parkovací objekty a parkovací plochy obecně do plochy areálů zahrnuté nejsou, vyjma případů, kdy jsou integrované přímo $\mathrm{v}$ budovách.

Celková plocha akcí byla vypočtena na základě statistiky UFI jako součet ploch všech akcí konaných $\mathrm{v}$ jednom kalendářním roce s přihlédnutím $\mathrm{k}$ délce jejich trvání. Slouží ke srovnání míry využití prostoru jednotlivých areálů a jejich plochy a představuje indikátor jejich skrytého prostorového potenciálu.
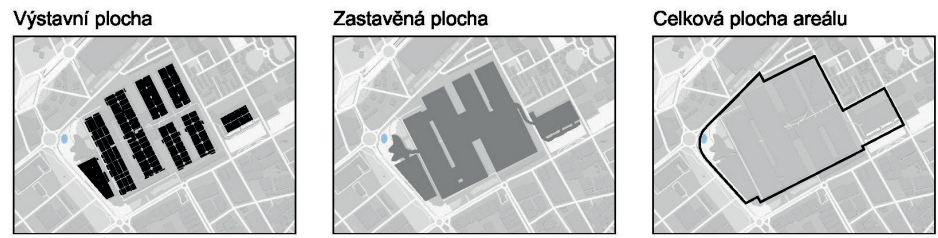

Obr. 6. Ukázka výstavní, zastavěné a celkové plochy areálu vymezené na př́íladu areálu Barcelona Gran Via

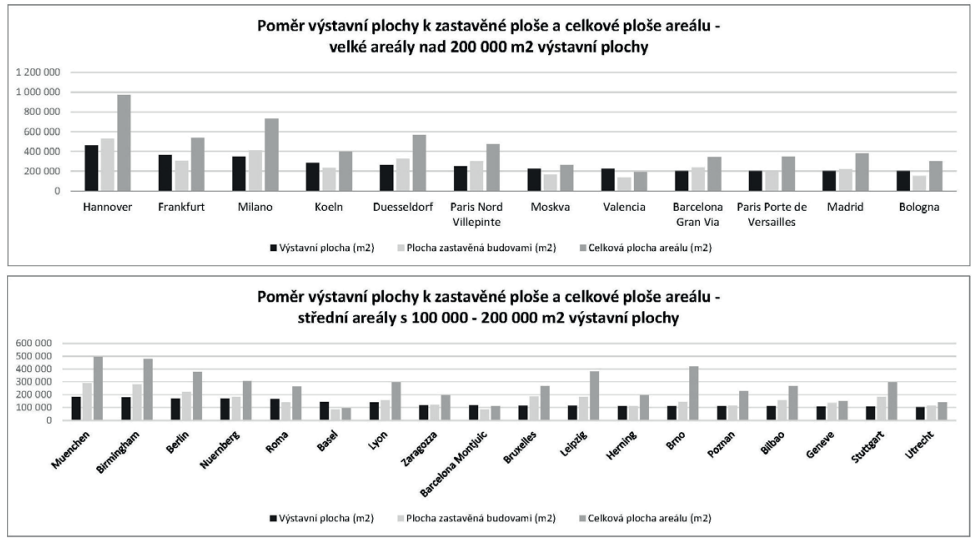

Tab. 2. Poměr výstavní plochy k ploše zastavěné budovami a k celkové ploše areálu u třiceti největších evropských veletržních areálů. Standardně je celková výstavní plocha menší než celková plocha zastavěná budovami (což vyplývá z halového charakteru zástavby), u některých areálů však výstavní plocha celkovou zastavěnou plochu převyšuje. To lze vysvětlit pouze mimořádně efektivním využitím prostoru, nejčastěji umístěním výstavní plochy ve více úrovních. 


\section{Prostorová efektivita vybraných areálů}

\begin{tabular}{|c|c|c|c|c|c|}
\hline $\begin{array}{l}\text { Areál } \\
\text { (zkrácené označení) }\end{array}$ & $\begin{array}{l}\text { Výstavní } \\
\text { plocha 1) }\end{array}$ & $\begin{array}{c}\text { Celková plocha } \\
\text { areálu 2) }\end{array}$ & $\begin{array}{c}\text { Celková plocha } \\
\text { akci 3) }\end{array}$ & $\begin{array}{c}\text { Pomèr výstavní } \\
\text { plochy k ploše akci }\end{array}$ & $\begin{array}{c}\text { Poměr plochy areálu } \\
\text { k ploše akci }\end{array}$ \\
\hline Hannover & 463275 & 973183 & 6709058 & 14,5 & \begin{tabular}{|c|}
6,9 \\
\end{tabular} \\
\hline Frankfurt & 366637 & 533535 & 3486471 & 9,5 & 6,5 \\
\hline Koeln & 284000 & 397034 & 4014034 & 14,1 & 10,1 \\
\hline Duesseldorf & 261817 & 569663 & 5503057 & 21,0 & 9,7 \\
\hline Madrid & 200000 & 382248 & 4379236 & 21,9 & 11,5 \\
\hline Basel & 141000 & 94090 & 3093778 & 21,9 & 32,9 \\
\hline Lyon & 138336 & 294399 & 1565502 & 11,3 & 5,3 \\
\hline Bruxelles & 115000 & 266895 & 3816691 & 33,2 & 14,3 \\
\hline Leipzig & 113300 & 380381 & 683102 & 6,0 & 1,8 \\
\hline Brno & 110000 & 570788 & 556678 & 5,1 & 1,0 \\
\hline Poznan & 109071 & 229045 & 1285679 & 11,8 & 5,6 \\
\hline Bilbao & 108000 & 268353 & 832278 & 7,7 & 3,1 \\
\hline Geneve & 106000 & 150435 & 1868320 & 17,6 & 12,4 \\
\hline Stuttgart & 105200 & 296634 & 1734896 & 16,49 & 5,85 \\
\hline
\end{tabular}

Tab. 3. Prostorová efektivita vyjádřená jako poměr celkové plochy akcí v průběhu jednoho roku k výstavní ploše a k ploše areálu

\section{Závěrečné shrnutí}

Z uvedených tři typů charakteristik mají finanční charakteristiky specifickou vypovídací hodnotu, pokud jde o vztah areálů k městu. Pokud se velikost výstavní plochy př́liš neliší od celkové plochy areálu (tab. 2), jde o efektivně organizovaný, stabilizovaný areál, současně však platí, že př́slušný areál vyčerpal možnosti svého rozvoje v př́slušné lokalitě a v př́padě dalšího nárůstu akcí bude muset jeho provozovatel uvažovat o časově a finančně náročném procesu relokace celého výstaviště do nové lokality. Opačná situace, kdy je výstavní plocha výrazně menší než celková plocha areálu, indikuje bud' dostatečně velký rozvojový potenciál, nebo méně efektivní využití celkové dostupné plochy. Výsledek porovnání celkové plochy akcí v průběhu roku s celkovou výstavní plochou a s plochou areálu (tab. 3) funguje jako orientační ukazatel prostorové efektivity, i když rozdíly v hodnotách tohoto ukazatele mohou být ovlivněny odlišným zaměřením jednotlivých areálů nebo různým charakterem pořádaných akcí.

Výzkum výstavních areálů a veletržních areálů a tento prríspěvek byly podpořeny v rámci juniorského mezifakultního grantového projektu FA-FAST 5930 Charakteristiky evropských výstavních a veletržních areálů, realizovaného v období 3/2019-1/2020 s finanční podporou VUT Brno. 


\section{Použité zkratky}

BIE - Bureau International des Expositions

Expo - zkrácený tvar anglického slova exposition a francouzského exposition

UFI - Union des foires internationales - The Global Association of the Exhibition Industry

\section{Reference}

Euro Fair Statistics 2017, 2017. Industry Resources: Surveys and Studies [online]. UFI The Global Association of the Exhibition Industry, September 2018. [cit. 9. 7. 2019]. Dostupné z: https://www.ufi.org/wp-content/uploads/2018/10/2017_euro_ fairs_statistics.pdf.

World Map of Exhibition Venues, 2017. Industry Resources: Surveys and Studies [online]. UFI The Global Association of the Exhibition Industry, Revisited December 2018. [cit. 10. 7. 2019]. Dostupné z: https://www.ufi.org/wp-content/uploads/2018/12/UFI_World_Map_of_Venues_2017_revDec18.pdf.

\section{Ilustrace}

Obr. 1-6 Štěpánková, Lenka, 2019, s využitím mapových podkladů OpenStreetMaps [download 6. 7. 2019]. Dostupné z: https://cadmapper.com/.

Tab. 1-3 Štěpánková, Lenka, 2019. 